Огляди літератури, оригінальні дослідження, погляд на проблему

УдК 616.12:577.175.522-073.97-085.356:547.972.35-055.1-092.9

DOI 10.11603/1811-2471.2018.v0.i1.8633

\title{
ЗМІНИ ПОКАЗНИКІВ ЕЛЕКТРОКАРДІОГРАМ ПРИ АДРЕНАЛІНОВО-КАЛЬЦІЄВІЙ МОДЕЛІ УРАЖЕННЯ СЕРЦЯ ЩУРІВ-САМЦІВ ТА ЗАСТОСУВАННІ 3 МЕТОЮ КОРЕКЦІЇ КВЕРЦЕТИНУ
}

\author{
๑А. М. Мусієнко, О. В. Денефіль, Ю. Ю. Яриш
}

ДВНЗ «Тернопільський державний медичний університет імені І. Я. Горбачевського МОз України»

РЕзЮМЕ. Вступ. Актуальним завданням сьогодення $є$ дослідження кардіопротекторних засобів при розвитку серцево-судинної патології, одним із яких $\epsilon$ кверцетин.

Мета дослідження - визначити зміни показників електрокардіограм (ЕКГ) у щурів-самців з адреналіновокальцієвою моделлю ураження міокарда (АКМ) та провести корекцію патологічного процесу кверцетином.

Матеріал і методи. Досліди виконано на щурах-самцях лінії Вістар (контроль, 1 год, 2 год, 24 год, 3, 7, 14, 21, 28 діб АКМ, кверцетин (Кв), 7 діб АКМ + Кв, 14 діб АКМ + Кв, 21 доба АКМ + Кв, 28 діб АКМ + Кв). Для реєстрації і аналізу ЕКГ використано пристрій “Кардіолаб".

Результати. У групі 28 діб АКМ летальність була 16,67 \%, у групі 28 діб AKM + Кв - 8,33 \%. Протягом всього експерименту у тварин зберігається брадикардія. Через 2 години подовжується інтервал PQ, відхилення сегмента ST відносно ізолінії стають суттєвими, знижується амплітуда зубця Р. Через 24 години з'являються високі загострені зубці T. Через 3 доби - подовження інтервалів PQ, QTc, низька амплітуда зубця Р. Через 7 діб - подовження інтервалу QTc, збільшення амплітуди зубців R, T, відхилення сегмента ST. Через 14 діб подовжуються тривалості інтервалів PQ, QTc, достовірні відхилення сегмента ST відносно ізолінії. Через 21 добу - подовжені тривалості інтервалів PQ, QTс, зменшується амплітуда зубця T.

Кверцетин має протекторний вплив вже через 7 днів після введення.

Висновки. Уведення адреналіну гідротартрату і глюконату кальцію щурам призводить до змін на ЕКГ хвилеподібного характеру. Кверцетин має протекторний вплив на розвиток адреналіново-кальцієвого ураження серця щурів.

КлючОВІ СлОВА: серце; адреналіново-кальцієве ураження; кверцетин; електрокардіограма; щури.

Вступ. Серцева недостатність $€$ однією з основних причин захворюваності та смертності в світі. Однією з причин ії розвитку $є$ інфаркт міокарда, коли кардіоміоцити гинуть внаслідок тривалої ішемії [1]. Інфаркт міокарда $\epsilon$ динамічним процесом, який супроводжується переходом оборотних змін до незворотного ішемічного пошкодження і завершується заміною змертвілої частини міокарда фіброзним рубцем. Розвиток фіброзу $\epsilon$ також динамічним процесом, в якому міофібробласти, головні клітинні елементи фіброзу, $\epsilon$ не тільки метаболічно активними і здатними до виробництва та позитивної регуляції цитокінів, але й мають скоротливі властивості, що допомагає хворим із серцевою недостатністю [2-4].

Оскільки основними патогенетичними ланками $\epsilon$ розвиток запалення, оксидантнонітрозамінний вибух, спазм коронарних судин, розвиток некрозів, активація фіброзоутворення $[5,6]$, доцільним $\epsilon$ вивчення ефективності кардіопротекторної дії препаратів, які 6 діяли на основні ланки патогенезу. До таких засобів можна віднести кверцетин, який має антиоксидантні, спазмолітичні, протизапальні, антисклеротичні властивості [7].

Для експериментів використовують лабораторних тварин, зокрема щурів. У них будова коронарних судин відмінна від людей. Кровопостачання серця здійснюється за рахунок лівої і правої вінцевих артерій, які не мають багаточисельних колатералей. Ліва коронарна артерія проходить у борозні між лівим предсердям і легеневою артерією, інтраміокардіально. Щури не мають справжньої огинаючої артерії серця [8]. Тому ЕКГ-ознаки інфаркту міокарда будуть відрізнятися від такого у людини.

Мета дослідження - визначити зміни показників електрокардіограм (ЕКГ) у щурів самців 3 адреналіново-кальцієвою моделлю ураження міокарда (АКМ) та провести корекцію патологічного процесу кверцетином.

Матеріал і методи дослідження. Досліди виконано на 143 щурах-самцях лінії Вістар віком 5-6 місяців. Тварин поділено на 14 груп (контроль, 1 год, 2 год, 24 год, 3 доби, 7 діб, 14 діб, 21 доба, 28 діб АКМ, кверцетин (Кв), 7 діб АКМ + Кв, 14 діб $A K M+$ Кв, 21 доба АКМ + Кв, 28 діб АКМ + Кв). У кожній з груп було по 10 самців. Щурам вводили одноразово внутрішньом'язово $0,18 \%$ розчин адреналіну гідротартрату з розрахунку 0,5 мг/кг маси (Фармацевтична фірма "Дарниця", Україна) і внутрішньоочеревинно 5 \% розчин глюконату кальцію ("Дніпрофарм", Україна) з розрахунку 1 мл/100 г маси тварини. Для корекції вводили інтраперитонеально розчин кверцетину з розрахунку 200 мг/кг маси. У групі 28 діб АКМ летальність була 16,67 \%, у групі 28 діб АКМ + Кв - 8,33\%.

Усі експерименти проводили в першій половині дня в спеціально відведеному приміщенні 
Огляди літератури, оригінальні дослідження, погляд на проблему

при температурі $18-22^{\circ} \mathrm{C}$, відносній вологості $40-$ $60 \%$ і освітленості 250 лк. Досліди виконано з дотриманням норм Конвенції Ради Європи про захист хребетних тварин, що використовуються для досліджень та інших наукових цілей (Страсбург, 18.03.1986 р.), ухвали Першого національного конгресу з біоетики (Київ, 2001) і наказу МО3 України № 690 від 23.09.2009 р.

Для дослідження ЕКГ використано пристрій “Кардіола6" (Харків, Україна) з комп'ютерним аналізом тривалості і амплітуди зубців і інтервалів. Реєстрацію ЕКГ проводили після попередньо-

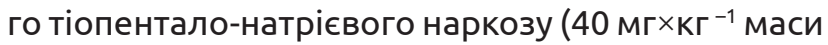
тіла тварини внутрішньочеревно).

Статистичну обробку цифрових даних виконано за допомогою програмного забезпечення «Excel» («Microsoft», CШA) та «STATISTICA» 6.0 ("Statsoft», США). Достовірність різниці значень між незалежними кількісними величинами визначали при нормальному розподілі за критерієм Стьюдента, в інших випадках - за допомогою непараметричних методів.

Результати й обговорення. У дослідах виявлено смертність тварин на пізніх етапах дослідження. Вона може бути пов'язана з розвитком інфаркту міокарда, а також з порушенням у роботі натрій-калієвої- та натрій-кальцієвої-АТФаз, коли у тварини виникає гіперкаліємія. При гіперкаліємії спостерігаються наступні зміни на ЕКГ: високі загострені зубці T, розширення комплексу QRT $\rightarrow$ сповільнення атріовентрикулярної провідності, подовження інтервалу PQ $\rightarrow$ зникнення зубця $\mathrm{P} \rightarrow$ зниження амплітуди зубця $\mathrm{R} \rightarrow$ депресія сегмента ST $\rightarrow$ фібриляція шлуночків і зупинка серця в діастолу [9]. При дослідженні показників ЕКГ нами виявлено наступні зміни (табл. 1, 2).

Терміни, коли ми проводили корекцію, взято через 7, 14, 21, 28 діб після викликання ураження серця. Згідно з даними літератури, 7 доба відповідає наявності запального процесу, інфільтрації зони пошкодження макрофагами, утворенню грануляційної тканини навколо ділянки пошкодження, на 12 добу спостерігається активація процесів формування рубцевої тканини і відкладання колагену без утворення колагенових волокон, острівці некротизованих кардіоміоцитів, їх набряк у позаінфарктній зоні. На 17 добу були початкові етапи формування сполучної тканини, сформовані колагенові волокна, інтрацелюлярний набряк кардіоміоцитів, на 25 - активне формування і структуризація сполучної тканини, заміщення некротичної тканини рубцевою [10]. Тобто вибрані нами терміни відповідають основним стадіям розвитку інфаркту міокарда.

ЧСС була меншою, порівняно з контролем, через 1 годину (на 8,8\%, p<0,001), 2 години (на

Таблиця 1. Зміни показників електрокардіограми у тварин у II стандартному відведенні при розвитку

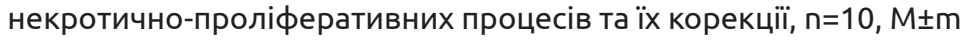

\begin{tabular}{|c|c|c|c|c|c|c|}
\hline \multirow[b]{2}{*}{ Група } & \multicolumn{6}{|c|}{ Показник } \\
\hline & ЧСС, $\mathrm{xB}^{-1}$ & інтервал RR, мc & зубець P, мс & $\begin{array}{c}\text { інтервал PQ, } \\
\text { мс }\end{array}$ & $\begin{array}{c}\text { інтервал QT, } \\
\text { мс }\end{array}$ & $\begin{array}{c}\text { інтервал QTc, } \\
\text { мс }\end{array}$ \\
\hline Контроль & $510,30 \pm 4,11$ & $117,60 \pm 0,93$ & $8,60 \pm 0,94$ & $37,00 \pm 1,82$ & $68,60 \pm 3,06$ & $137,10 \pm 0,59$ \\
\hline 1 год AKM & $465,50 \pm 9,15^{*}$ & $129,20 \pm 2,50 *$ & $8,00 \pm 0,67$ & $41,20 \pm 1,94$ & $61,80 \pm 6,39$ & $144,10 \pm 1,43^{*}$ \\
\hline 2 год АКМ & $415,40 \pm 8,95 *, \#$ & $145,00 \pm 2,93 *$,\# & $14,60 \pm 0,77^{*}, \#$ & $46,80 \pm 0,95^{*}, \#$ & $82,20 \pm 3,29 *$,\# & $142,40 \pm 10,35$ \\
\hline 24 год AKM & $494,60 \pm 11,68 \#$ & $121,90 \pm 2,83 \#$ & $8,80 \pm 0,58 \#$ & $35,80 \pm 2,72 \#$ & $73,00 \pm 3,80$ & $139,60 \pm 1,58$ \\
\hline 3 доби AKM & $435,80 \pm 11,94^{*}, \#$ & $138,80 \pm 3,84^{*}, \#$ & $12,60 \pm 1,06 *$,\# & $45,80 \pm 1,25^{*}, \#$ & $70,00 \pm 1,99$ & $148,90 \pm 2,05 *$,\# \\
\hline 7 діб АКМ & $480,50 \pm 7,24 *, \#$ & $125,20 \pm 1,98^{*}, \#$ & $8,40 \pm 1,18 \#$ & $38,40 \pm 1,18 \#$ & $70,00 \pm 1,76$ & $141,50 \pm 1,13^{*}$, \# \\
\hline 14 діб АКМ & $429,30 \pm 14,58 *, \#$ & $141,20 \pm 4,55^{*}, \#$ & $13,60 \pm 1,15^{*}, \#$ & $43,80 \pm 1,96 *$,\# & $72,00 \pm 2,78$ & $150,10 \pm 2,48 *$,\# \\
\hline 21 доба AKM & $447,80 \pm 7,36 *$ & $134,40 \pm 2,19 *$ & $12,60 \pm 1,16^{*}$ & $42,60 \pm 1,03^{*}$ & $68,20 \pm 4,66$ & $146,60 \pm 1,23^{*}$ \\
\hline 28 діб АКМ & $439,00 \pm 12,51 *$ & $137,80 \pm 3,98 *$ & $14,20 \pm 0,87 *$ & $42,20 \pm 2,07$ & $73,80 \pm 2,07$ & $148,20 \pm 2,19$ \\
\hline Кверцетин & $436,00 \pm 19,65^{*}$ & $140,40 \pm 7,05^{*}$ & $13,40 \pm 1,16^{*}$ & $45,20 \pm 2,69 *$ & $73,20 \pm 6,10$ & $149,60 \pm 3,63^{*}$ \\
\hline $\begin{array}{l}7 \text { діб АКМ + } \\
\text { Кв }\end{array}$ & $477,00 \pm 6,06^{*}, * *$ & $126,00 \pm 1,63^{*}$ & $11,20 \pm 0,82^{*}$ & $38,40 \pm 2,14$ & $75,60 \pm 2,35$ & $142,00 \pm 0,92^{*}$ \\
\hline $\begin{array}{l}14 \text { діб AКM + } \\
\text { Кв }\end{array}$ & $432,00 \pm 6,56 *, \#$ & $139,20 \pm 2,07 *$,\# & $11,00 \pm 0,79$ & $43,20 \pm 1,64 *$ & $75,40 \pm 3,13$ & $149,40 \pm 1,15^{*}, \#$ \\
\hline $\begin{array}{l}21 \text { доба АКМ+ } \\
\text { Кв }\end{array}$ & $484,10 \pm 12,37 \&$ & $124,60 \pm 3,17 *, \&$ & $9,40 \pm 0,94 * *, \&$ & $42,00 \pm 0,94^{*}$ & $66,00 \pm 2,85$ & $141,10 \pm 1,82 \&$ \\
\hline $\begin{array}{l}28 \text { діб AKM + } \\
\text { Кв }\end{array}$ & $466,80 \pm 6,70 *$ & $128,80 \pm 1,84^{*}$, ,*,$\&$ & $10,00 \pm 0,77^{* *}, \&$ & $41,80 \pm 1,70$ & $74,40 \pm 2,47$ & $143,40 \pm 1,06^{*}$ \\
\hline
\end{tabular}

Примітки: 1. * - показники достовірні порівняно з контролем;

2. ** - показники достовірні порівняно з кверцетином;

3. \# - показники достовірні порівняно з попереднім терміном дослідження;

4. \& - показники достовірні порівняно з результатами без корекції. 
Огляди літератури, оригінальні дослідження, погляд на проблему

Таблиця 2. Зміни показників електрокардіограми у тварин у II стандартному відведенні при розвитку некротично-проліферативних процесів та їх корекції, $n=10, M \pm m$

\begin{tabular}{|c|c|c|c|c|c|c|}
\hline \multirow[b]{2}{*}{ Група } & \multicolumn{6}{|c|}{ Показник } \\
\hline & $\begin{array}{c}\text { Зубець } \mathrm{P}, \\
\text { мB }\end{array}$ & $\begin{array}{c}\text { Iнтервал QRS, } \\
\text { мс }\end{array}$ & $\begin{array}{c}\text { Зубець R, } \\
\text { мB } \\
\end{array}$ & $\begin{array}{c}\text { Зубець T, } \\
\text { мВ }\end{array}$ & $\begin{array}{c}\text { СП, } \\
\% \\
\end{array}$ & $\begin{array}{c}\text { Сегмент ST, } \\
\text { мс }\end{array}$ \\
\hline Контроль & $0,064 \pm 0,016$ & $17,00 \pm 2,09$ & $0,61 \pm 0,04$ & $0,17 \pm 0,01$ & $58,50 \pm 2,84$ & $0,028 \pm 0,017$ \\
\hline 1 год АКМ & $0,034 \pm 0,016$ & $19,40 \pm 1,89$ & $0,61 \pm 0,05$ & $0,11 \pm 0,04$ & $47,60 \pm 4,35^{*}$ & $0,014 \pm 0,035$ \\
\hline 2 год AKM & $0,119 \pm 0,010$ & $20,00 \pm 1,33$ & $0,53 \pm 0,06$ & $0,26 \pm 0,05^{\#}$ & $56,80 \pm 1,63$ & $0,149 \pm 0,052^{*}, \#$ \\
\hline 24 год АКМ & $0,097 \pm 0,009$ & $19,80 \pm 2,30$ & $0,69 \pm 0,06^{\#}$ & $0,26 \pm 0,02^{*}$ & $60,50 \pm 4,01$ & $0,086 \pm 0,030$ \\
\hline 3 доби АКМ & $0,097 \pm 0,009$ & $15,60 \pm 0,62$ & $0,69 \pm 0,03$ & $0,22 \pm 0,02$ & $51,70 \pm 2,48$ & $0,051 \pm 0,016$ \\
\hline 7 діб АКМ & $0,098 \pm 0,017$ & $16,60 \pm 0,77$ & $0,83 \pm 0,08^{*}$ & $0,24 \pm 0,02^{*}$ & $56,10 \pm 1,54$ & $0,196 \pm 0,040^{*}, \#$ \\
\hline 14 діб АКМ & $0,107 \pm 0,008$ & $18,60 \pm 1,49$ & $0,59 \pm 0,04^{\#}$ & $0,18 \pm 0,02^{\#}$ & $51,40 \pm 2,47$ & $0,079 \pm 0,015^{*}, \#$ \\
\hline 21 доба АКМ & $0,094 \pm 0,011$ & $21,00 \pm 1,58$ & $0,55 \pm 0,03$ & $0,11 \pm 0,02^{*}, \#$ & $50,90 \pm 3,81$ & $0,041 \pm 0,021$ \\
\hline 28 діб АКМ & $0,131 \pm 0,010$ & $19,40 \pm 1,40$ & $0,58 \pm 0,01$ & $0,13 \pm 0,02$ & $53,60 \pm 1,63$ & $0,012 \pm 0,011^{\#}$ \\
\hline Кверцетин & $0,120 \pm 0,007$ * & $17,80 \pm 2,34$ & $0,55 \pm 0,03$ & $0,22 \pm 0,02^{*}$ & $51,70 \pm 2,43$ & $0,062 \pm 0,045$ \\
\hline 7 діб АКМ + Кв & $0,091 \pm 0,009$ & $22,20 \pm 2,46$ & $0,69 \pm 0,05^{\text {** }}$ & $0,21 \pm 0,02$ & $60,00 \pm 2,04$ & $0,008 \pm 0,033^{\&}$ \\
\hline 14 діб АКМ + Кв & $0,087 \pm 0,011$ & $19,60 \pm 1,91$ & $0,74 \pm 0,04^{*, * *, \&}$ & $0,22 \pm 0,02^{*}$ & $54,10 \pm 1,69$ & $0,105 \pm 0,015^{*, * * \#}$ \\
\hline 21 доба АКМ + Кв & $0,078 \pm 0,013$ & $15,60 \pm 0,76$ & $0,74 \pm 0,05^{* *, \&}$ & $0,18 \pm 0,02^{\&}$ & $53,00 \pm 1,65$ & $0,067 \pm 0,020^{* *}$ \\
\hline 28 діб АКМ + Кв & $0,076 \pm 0,015$ & $18,00 \pm 1,91$ & $0,66 \pm 0,06$ & $0,17 \pm 0,01^{* *}$ & $58,10 \pm 2,16$ & $0,027 \pm 0,021$ \\
\hline
\end{tabular}

Примітки: 1. * - показники достовірні порівняно з контролем;

2. ** - показники достовірні порівняно з кверцетином;

3. \# - показники достовірні порівняно з попереднім терміном дослідження;

4. \& - показники достовірні порівняно з результатами без корекції.

$18,6 \%, p<0,001), 3$ доби (на 17,6\%, $p<0,001), 7$ діб (на 5,8\%, $\mathrm{p}<0,001$ ), 14 діб (на 15,9\%, $\mathrm{p}<0,001$ ), 21 добу (на 12,2 \%, р<0,001) і 28 діб (на $14 \%$, p<0,001). Відповідно, у ці терміни була достовірно більшою тривалість інтервалу RR.

Відмічено зростання тривалості зубця Р, порівняно з контролем:через 2 години (на $69,8 \%, p<0,001)$, 3 доби (на 46,5\%, p<0,01), 14 діб (на 58,1\%, p<0,001), 21 добу (на 46,5 \%, р<0,01) і 28 діб (на 65,1\%, $\mathrm{p}<0,001)$. Тривалість інтервалу PQ зросла через 2 години (на 26,5\%, $\mathrm{p}<0,001), 3$ доби (на 23,8\%, $\mathrm{p}<0,001)$, 14 діб (на 18,4 \%, p<0,01), 21 добу (на 15,1\%, p<0,01).

Тривалість інтервалу QT зросла тільки через 2 години (на 19,8 \%, p<0,001). Тривалість інтервалу QTс зросла через 1 годину (на 5,1\%, $<<0,001$ ), 3 доби (на 8,6 \%, p<0,01), 7 діб (на $3,2 \%, p<0,001$ ), 14 діб (на 9,5\%, p<0,001), 21 добу (на 6,9\%, p<0,01) і 28 діб (на 8,1\%, p<0,001). Систолічний показник (СП) зменшився на $18,63 \%(p<0,001)$ тільки через 1 годину.

Зменшилася амплітуда зубця Р через 2 години (на 85,9\%, p<0,001), 3 доби (на 90,6\%, $<<0,01), 14$ діб (на $67,2 \%, p<0,001), 28$ діб (у 2 рази, $p<0,001)$. Амплітуда зубця R зросла тільки через 7 діб (на $36 \%$, $\mathrm{p}<0,001)$. Амплітуда зубця Т зросла достовірно через 24 години (на 51,1\%, p<0,001), 7 діб (на 40,2\%, p<0,001) і зменшилася через 21 добу (на $38,5 \%$, p<0,002). Достовірне відхилення сегмента ST відносно ізолінії, порівняно з контролем, відмічено через 2 години (у 5,3 раза, p<0,001), через 7 діб (у 7 разів, $p<0,001)$ і через 14 діб (у 2,8 раза, $p<0,001)$.
Кверцетин привів до зменшення ЧСС (на $14,6 \%, p<0,001)$, зростання тривалості інтервалу RR (на $19,4 \%, p<0,002)$, зубця P (на $55,8 \%, p<0,002$ ), інтервалів PQ (на 22,16\%, P<0,01), QTc (на 9,1\%, $\mathrm{p}<0,001)$, амплітуди зубців P (на $87,5 \%, \mathrm{p}<0,002)$ i Т (на 28,2 \%, $\mathrm{p}<0,02)$.

Розвиток некротично-проліферативних процесів при адреналіново-кальцієвій моделі кардіосклерозу при корекції патологічного процесу кверцетином призвів до наступного. Через 7 діб у тварин, яким вводили кверцетин, була більшою тривалість інтервалу QRS (на 33,7 \%, p<0,05), менше відхилення сегмента ST відносно ізолінії (на $95,9 \%, p<0,001)$. Порівняно з контролем, у тварин зменшилася ЧСС (на 6,5\%, p<0,001), зросла тривалість інтервалу RR (на 7,1\%, $\mathrm{p}<0,002$ ), QTс (на $3,6 \%, p<0,001)$, зубця $\mathrm{P}$ (на $42,2 \%, p<0,05)$.

Через 14 діб у тварин, яким вводили кверцетин, була більшою амплітуда зубця R (на $24,7 \%$, $\mathrm{p}<0,002)$. Порівняно з контролем, у тварин була меншою ЧСС (на 15,3\%, p<0,001), більшою - тривалість інтервалів RR (на 18,4\%, $\mathrm{p}<0,001)$, PQ (на $16,8 \%, \mathrm{p}<0,01)$, QTc (на $9 \%, \mathrm{p}<0,001)$, амплітуди зубця R (на $21 \%, p<0,05), T$ (на $27 \%, p<0,05)$, відхилення сегмента ST відносно ізолінії (у 3,7 раза, $p<0,001)$.

Через 21 добу у тварин, яким вводили кверцетин, була більшою ЧСС (на $8,1 \%, \mathrm{p}<0,01)$, меншою - тривалість інтервалу RR (на 7,3\%, p<0,01), зубця P (на 25,4 \%, $\mathrm{p}<0,05$ ), інтервалу QRS (на $25,7 \%, p<0,002$ ), QTC (на $3,7 \%, p<0,02$ ), більшими 
Огляди літератури, оригінальні дослідження, погляд на проблему амплітуди зубця R (на 36,2%, p<0,002) і Т (на 70,1 \%, p<0,002). Порівняно з контролем, у тварин була більшою тривалість інтервалу PQ (на 13,5\%, p<0,01).

Через 28 діб у тварин, яким вводили кверцетин, була меншою тривалість зубця Р (на 29,6 \%, $\mathrm{p}<0,001)$ і його амплітуда (на $42 \%, \mathrm{p}<0,002$ ). Порівняно з контролем, у тварин була меншою ЧСС (на 9,5\%, p<0,001), більшою - тривалість інтервалів RR (на 16,3\%, p<0,001), QTс (на 4,6\%, p<0,001).

Таким чином, у експерименті підтверджено твердження про те, що у тварин виникає інфаркт міокарда, пов'язаний із ураженням задньо-базальних відділів серця. Це, можливо, спричинене підвищенням тромбоутворення у різні терміни розвитку патологічного процесу. Проявляється це брадикардією вже через 1 годину після введення препаратів. Через 2 години процес поглиблюється - подовжується інтервал $\mathrm{PQ}$, відхилення сегмента ST відносно ізолінії стають суттєвими, брадикардія зберігається, знижується амплітуда зубця Р. Через 24 години патологічний процес ніби "зникає», але з'являються високі загострені зубці Т, що вказує на порушення роботи іонних помп. Через 3 доби знов настає погіршення: брадикардія, подовження інтервалів PQ, QTc, низька амплітуда зубця Р. Через 7 діб - брадикардія, подовження інтервалу QTc, зростає амплітуда зубців R, T, відхилення сегмента ST відносно ізолінії стають найбільшими. Через 14 діб брадикардія наростає, подовжуються тривалості інтервалів PQ, QTс, залишається достовірним відхилення сегмента ST відносно ізолінії. Через 21 добу: брадикардія, по- довжені тривалості інтервалів PQ, QTc, зменшується амплітуда зубця Т. Через 28 діб залишається брадикардія, але відмічено тенденцію до їі зменшення.

Кверцетин має протекторний вплив вже через 7 днів після введення: відмічено нормалізацію положення сегмента ST відносно ізолінії. Через 14 днів зростає амплітуда зубця R, через 21 добу - відсутня брадикардія, зміни інтервалу QTс, амплітуда зубця R, T. Через 28 діб тривалість зубця $\mathrm{P}$ суттєво менша. Тобто з отриманих даних можна зробити висновок, що кверцетин через 7 діб має виражений протизапальний вплив. Покращення процесів деполяризації шлуночків через 14 діб може вказувати на менше некрозоутворення, через 21 - менший набряк кардіоміоцитів, формування сполучної тканини. Очевидно, кверцетин у наших дослідженнях спричинив протизапальний, антисклеротичний ефект у щурів з моделлю адреналіново-кальцієвого ураження серця.

Висновки. 1. Уведення адреналіну гідротартрату і глюконату кальцію щурам призводить до змін на ЕКГ хвилеподібного характеру.

2. Кверцетин має протекторний вплив на розвиток адреналіново-кальцієвого ураження серця щурів.

Перспективи подальших досліджень. У подальшому буде проведено мікроскопічне дослідження міокарда щурів та вивчено зміни інтерлейкінів при розвитку адреналіново-кальцієвого ураження серця та корекції патологічного процесу кверцетином.

\section{ЛITEPATУPA}

1. Hashmi S. Acute myocardial infarction and myocardial ischemia-reperfusion injury: a comparison / S. Hashmi, S. Al-Salam // Int. J. Clin. Exp. Pathol. - 2015. - Vol. 8 (8). P. 878-896.

2. Myofibroblast-mediated mechanisms of pathological remodelling of the heart / K. T. Weber, Y. Sun, S. K. Bhattacharya [et al.] // Nat. Rev. Cardiol. - 2013. - Vol. 10 (1). P. 15-26.

3. Segura A. M. Fibrosis and heart failure / A. M. Segura, O. H. Frazier, L. M. Buja // Heart Fail. Rev. - 2014. Vol. 19 (2). - P. 173-185.

4. TWEAK/Fn14 axis is a positive regulator of cardiac hypertrophy / T. Novoyatleva, W. Janssen, A. Wietelmann [et al.] // Cytokine. - 2013. - Vol. 64 (1). - P. 43-45.

5. Monocytes/macrophages prevent healing defects and left ventricular thrombus formation after myocardial infarction / S. Frantz, U. Hofmann, D. Fraccarollo [et al.] // FASEB J. - 2013. - Vol. 27 (3). - P. 871-881.

6. Frangogiannis N. G. Inflammation in cardiac injury, repair and regeneration / N. G. Frangogiannis // Curr. Opin. Cardiol. - 2015. - Vol. 30 (3). - P. 240-245.
7. Шеремета Л. М. Противиразкова дія ліпосомального кверцетину при субхронічній виразці шлунка в експерименті / Л. М. Шеремета // Вісник Сумду. Серія «Медицина». - 2008. - № 1. - С. 43-47.

8. Experimental myocardium infarction in rats: analysis of the model / L. A. Zornoff, S. A. Paiva, M. F. Minicucci, J. Spadaro // Arq. Bras. Cardiol. - 2009. Vol. 93, No. 4 São Paulo Oct. http://dx.

9. Клиническая интерпретация лабораторных исследований для практикующего врача / под общ. ред. С. Г. Щербака. - СПб. : Издательство «Корона.Век»; М. : Издательство БИНОМ, 2015. - 464 с.

10. Мазуркевич А. Й. Гістологічні зміни у міокарді щурів за експериментально сформованої ішемії / А. Й. Мазуркевич, В. В. Ковпак, О. С. Ковпак // Наукові доповіді Національного університету біоресурсів і природокористування України. - 2016. - Т. 63, № 6. - Режим доступу: http://nbuv.gov.ua/UJRN/Nd_2016_6_26. 
Огляди літератури, оригінальні дослідження, погляд на проблему REFERENCES

1. Hashmi, S., \& Al-Salam, S. (2015). Acute myocardial infarction and myocardial ischemia-reperfusion injury: a comparison. Int. J. Clin. Exp. Pathol., 8 (8), 878-896.

2. Weber, K.T., Sun, Y., Bhattacharya, S.K., Ahokas, R.A., \& Gerling, I.C. (2013). Myofibroblast-mediated mechanisms of pathological remodelling of the heart. Nat. Rev. Cardiol., 10(1), 15-26.

3. Segura, A.M., Frazier, O.H., \& Buja, L.M. (2014). Fibrosis and heart failure. Heart Fail. Rev., 19 (2), 173-185.

4. Novoyatleva, T., Janssen, W., Wietelmann, A., Schermuly, R.T., \& Engel, F. B. (2013). TWEAK/Fn14 axis is a positive regulator of cardiac hypertrophy. Cytokine, 64 (1), 4345.

5. Frantz, S., Hofmann, U., Fraccarollo, D., Schäfer, A., Kranepuhl, S., Hagedorn, I., Nieswandt, B., et al. (2013). Monocytes/macrophages prevent healing defects and left ventricular thrombus formation after myocardial infarction. FASEB J. 27 (3), 871-881.

6. Frangogiannis, N.G. (2015). Inflammation in cardiac injury, repair and regeneration. Curr. Opin. Cardiol. 30 (3), 240-245.

7. Sheremeta, L.M. (2008). Protyvovyrazkova diia liposomalnoho quercetynu pry subkhronichnii vyraztsi shlun-

ka $v$ eksperymenti [Anti-ulcer effect of liposomal quercetin in subchronic ulcer of the stomach in the experiment]. Visnyk SumDU. Seriia "Medytsyna" - Herald of Sumy State University. The series "Medicine", 1, 43-47 [in Ukrainian].

8. Zornoff, L.A., Paiva, S.A., Minicucci, M.F., Spadaro, J. (2009). Experimental myocardium infarction in rats: analysis of the model. Arq. Bras. Cardiol., 93 (4), http://dx.doi. org/10.1590/S0066-782X2009001000018

9. Shcherbak, S.G. (Ed.). (2015). Clinicheskaya interpretatsiya laboratornykh issledovaniy dlya praktikuyushchego vracha [Clinical interpretation of laboratory research for a practitioner]. Saint-Petersburg: "Korona Vek" Moscow: BINOM [in Russian].

10. Mazurkevych, A.Y., Kovpak, V.V., \& Kovpak, O.S. (2016). Histolohichni zminy u miokardi shchuriv za eksperymentalno sformovanoi ishemii [Histological changes in myocardium of rats in experimentally formed ischemia]. Naukovi dopovidi Natsionalnoho universytetu bioresursiv $i$ pryrodokorystuvannia Ukrainy - Scientific Reports of the National University of Life and Environmental Sciences of Ukraine, 63 (6). - Retrieved from: http://nbuv.gov.ua/ UJRN/Nd_2016_6_26. [in Ukrainian].

\title{
ИЗМЕНЕНИЯ ПОКАЗАТЕЛЕЙ ЭЛЕКТРОКАРДИОГРАММ ПРИ АДРЕНАЛИНОВО- КАЛЬЦИЕВОЙ МОДЕЛИ ПОРАЖЕНИЯ СЕРДЦА КРЫС-САМЦОВ И ПРИМЕНЕНИИ С ЦЕЛЬЮ КОРРЕКЦИИ КВЕРЦЕТИНА
}

\author{
๑А. Н. Мусиенко, О. В. Денефиль, Ю.Ю. Ярыш
}

ГВУз «Тернопольский государственный медицинский университет имени И. Я. Горбачевского Мз Украины»

РЕзЮМЕ. Введение. Актуальной задачей современной медицины является исследование кардиопротекторных средств при развитии сердечно-сосудистой патологии, одним из которых является кверцетин.

Цель исследования - определить изменения показателей электрокардиограммы (ЭКГ) у крыс-самцов с адреналиново-кальциевой моделью поражения миокарда (АКМ) и провести коррекцию патологического процесса кверцетином.

Материал и методы. Опыты выполнены на крысах-самцах линии Вистар (контроль, 1 ч, 2 ч, 24 ч, 3, 7, 14, 21, 28 суток АКМ, кверцетин (Кв), 7 суток АКМ + Кв, 14 суток АКМ + Кв, 21 суток АКМ + Кв, 28 суток АКМ + Кв). Для регистрации и анализа ЭКГ использовано устройство "Кардиолаб".

Результаты. В группе 28 суток АКМ летальность была 16,67 \%, в группе 28 суток АКМ + Кв - 8,33 \%. Во время эксперимента у крыс сохраняется брадикардия. Через 2 часа - удлинялся интервал PQ, отклонение сегмента ST относительно изолинии становились существенными, снижалась амплитуда зубца Р. Через 24 часа появлялись высокие заостренные зубцы Т. Через 3 суток - удлинение интервалов PQ, QTc, низкая амплитуда зубца P. Через 7 суток - удлинение интервала QTc, увеличение амплитуды зубцов R, T, отклонение сегмента ST. Через 14 суток удлинялись интервалы PQ, QTc, оставались достоверными отклонения сегмента ST относительно изолинии. Через 21 день - удлинение интервалов PQ, QTc, уменьшение амплитуды зубца T.

Кверцетин обладал протекторными свойствами уже через 7 дней после введения.

Выводы. Введение адреналина гидротартрата и глюконата кальция крысам приводит к волнообразным изменениям на ЭКГ. Кверцетин обладает протекторным влиянием на развитие адреналиново-кальциевого поражения сердца крыс.

КЛЮЧЕВЫЕ СЛОВА: серце; адреналиново-кальциевое поражение; кверцетин; электрокардиограмма; крысы. 


\title{
CHANGES OF ELECTROCARDIOGRAM INDICATORS WITH ADRENALIN-CALCIUM MODEL OF HEART DAMAGE OF MALE RATS AND USING THE CORECTION OF QUERCETIN
}

\author{
๑A. M. Musiienko, O. V. Denfil, Yu. Yu. Yarysh \\ I. Horbachevsky Ternopil State Medical University
}

SUMMARY. Introduction. Actual task of the present day is to investigate cardioprotective medication in the development of cardiovascular pathology, one of which is quercetin.

The aim of the study was to determine changes in the parameters of electrocardiogram (ECG) in male rats with adrenalin-calcium myocardial injury (ACM) and to correct the pathological process by quercetin.

Material and Methods. Experiments were performed on male rats of the Wistar line (control, 1 hour, 2 hours, 24 hours, 3 days, 7 days, 14 days, 21 days, 28 days ACM, quercetin (Q), 7 days ACM + Q, 14 days ACM + Q, 21 days ACM + Q, 28 days ACM + Q). The apparatus "Cardiolab" was used for registration and analysis of ECG.

Results. In the group of 28 days of ACM the mortality rate was $16.67 \%$, in the group 28 days ACM + Q - 8.33\%. Throughout the experiment, animals have bradycardia. After 2 hours, the PQ interval is lengthened, the deviation of the ST segment relative to the isoline becomes significant, the amplitude of the wave $R$ was reduced. After 24 hours, high sharpened wave T appeared. After 3 days, prolongation of the intervals PQ, QTc, low amplitude of P wave. After 7 days elongation of the interval QTc, increase in the amplitude of the waves R, T, deviation of the segment ST. After 14 days, the lengths of the intervals PQ, QTc are prolonged, remains a significant deviation of the ST segment relative to the isolation. After 21 days, elongated of intervals PQ, QTc, decreases the amplitude of the T wave.

Quercetin has tread effect 7 days after the injection.

Conclusions. Injection of adrenaline hydrotartrate and calcium gluconate to rats causes changes in ECG in a wavelike manner. Quercetin has a tread effect on the development of adrenalin-calcium heart disease in rats.

KEY WORDS: heart; adrenalin-calcium defeat; quercetin; electrocardiogram; rat. 